\title{
Gambaran Dampak Kecemasan dan Gejala Psikologis pada Anak Korban Bencana Gempa Bumi di Lombok
}

\author{
Zurriyatun Thoyibah ${ }^{1, *}$, Meidiana Dwidiyanti², Misroh Mulianingsih ${ }^{1}$, \\ Winda Nurmayani ${ }^{1}$, Reza Indra Wiguna $^{3}$ \\ ${ }^{1}$ Program Studi Keperawatan, Stikes Yarsi Mataram, Indonesia \\ ${ }^{2}$ Departemen Ilmu Keperawatan, Fakultas Kedokteran, Universitas Diponegoro, Indonesia \\ ${ }^{3}$ Jurusan Ilmu Keperawatan Fakultas Kesehatan, Universitas Qomarul Huda Badarudin Bagu, Indonesia \\ oyiqyarsi@gmail.com
}

\begin{abstract}
Introduction: Earthquakes that occur always have a psychological impact on all victims, including children. Limited studies explore anxiety and symptoms of children's psychological problems. This study aims to describe anxiety and psychological symptoms on children caused by the earthquake in Lombok, West Nusa Tenggara.

Method: This study uses a mix-method design with a sample of 47 respondents in SDN 2 Penimbung West Lombok, the sample was determined by purposive sampling technique. Quantitative data analysis using the RCMAS-2 questionnaire (Revised Children's Manifest Anxiety Scale; second edition) and qualitative analysis using the method of in-depth interview.

Results: Most of the respondents of children included normal anxiety category $85.11 \%$, while $14.89 \%$ belonged to the category of clinical anxiety. The results of the qualitative study showed that there were changes in attitudes in children, such as children becoming more sensitive, easily crying, irritable, children easily panicking and crying if they heard something thundering, children often worried about entering the house, they were initially cheerful but after earthquakes occur more children are quiet and withdraw.

Conclusion: Earthquakes that occur cause symptoms of clinical anxiety in some children, which are manifested in everyday life both at home and at school. Future research is expected to provide appropriate therapy for children affected by disasters so that the psychological impact experienced can be reduced.
\end{abstract}

Keywords: Anxiety, Children, Earthquakes, Psychological effects.

\begin{abstract}
Abstrak
Pendahuluan: Bencana gempa bumi yang terjadi selalu membawa dampak psikologis terhadap semua korban termasuk pada anak-anak. Sedikit penelitian yang mengeksplore kecemasan dan gejala masalah psikologis pada anak-anak. Penelitian ini bertujuan untuk mengidentifikasi dampak kecemasan dan gejala psikologis pada anak-anak yang disebabkan oleh bencana gempa bumi di wilayah Lombok.

Metode: Desain yang digunakan dalam penelitian ini adalah mix-method dengan sampel sebanyak 47 responden di SDN 2 Penimbung Lombok Barat, sampel ditentukan dengan teknik purposive sampling. Analisis data kuantitaif menggunakan kuesioner RCMAS-2 (Revised Children's Manifest Anxiety Scale; second edition) dan analisis kualitiatif menggunakan metode wawancara mendalam dengan orang tua dan guru di sekolah.
\end{abstract}


Hasil: Sebagaian besar responden anak-anak termasuk kategori kecemasan normal 85,11\%, sedangkan $14,89 \%$ termasuk dalam kategori kecemasan klinis. Hasil studi kualitatif menunjukkan bahwa terjadi perubahan sikap pada anak-anak, seperti anak menjadi lebih sensitive, mudah menangis, mudah marah, anak-anak mudah panik dan menangis jika mendengar sesuatu yang bergemuruh, anak sering khawatir masuk rumah, mereka yang awalnya ceria namun setelah gempa terjadi anak lebih banyak pendiam dan menarik diri.

Kesimpulan: Gempa bumi yang terjadi menyebabkan terjadinya gejala kecemasan klinis pada sebagaian anak-anak, yang dimanfestasikan dalam kehidupan sehari-hari baik di rumah maupaun di sekolah. Penelitian selanjutnya diharapkan dapat memberikan terapi yang tepat bagi anak-anak korban bencana agar dampak psikologis yang dialami dapat berkurang.

Keywords: Anak-anak, Gejala psikologis, Gempa bumi, Kecemasan.

\section{PENDAHULUAN}

Gempa bumi menempati peringkat kedua di antara bencana alam paling mematikan yang mempengaruhi manusia (Şalcıŏ̆lu \& Başoğlu, 2008). Menurut data Badan Meteorologi Klimatologi dan Geofisika (BMKG), gempa bumi di Lombok terjadi dengan kronologi gempa berkekuatan 6,4 Skala Richter pada minggu 29 Juli 2018 pukul 06.47 WITA, disusul gempa berkekuatan 7,0 SR pada minggu 5 Agustus 2018 pukul 17.46 WITA, kemudian gempa berkekuatan 6,2 SR pada Kamis 9 Agustus 2018 pukul 00.25 WITA, dan gempa berkekuatan 6,9 SR pukul 22.56 WITA pada minggu 19 Agustus 2018 (BMKG, 2018).

Bencana gempa bumi yang terjadi secara berturut-turut di Lombok sejak tanggal 29 Juli 2018 tersebut membawa dampak yang luar biasa terhadap semua aspek kehidupan para korban bencana baik aspek fisik, sosial, dan psikologis. Korban gempa tidak hanya mengalami masalah darurat seperti kerusakan fisik akibat gempa, namun juga masalah kesehatan mental psikologis, seperti; masalah ansietas (kecemasan), stress (tekanan), depresi (kemurungan), dan trauma (Ramirez \& Peek-Asa, 2005). Gempa bumi secara konsisten terbukti berhubungan dengan masalah kesehatan mental seperti depresi dan gangguan stres paska-trauma, sebuah survey menunjukkan bahwa, setelah peristiwa bencana, sekitar 15-20\% populasi akan mengalami gangguan mental ringan atau sedang yang merujuk pada kondisi post-traumatic stress disorder (PTSD), sementara 3-4\% akan mengalami gangguan berat seperti psikosis, depresi berat dan kecemasan yang tinggi (Surendra et al, 2015).

Bencana memiliki pengaruh terbesar pada kelompok yang paling rentan terutama adalah kelompok usia anak-anak (Nakamura, 2005). Hal ini disebabkan karena anak-anak secara langsung mengalami, merasakan, dan menyaksikan dampak yang ditimbulkan akibat faktor usia yang masih belum matang secara pertumbuhan psikologis.

Penelitian sebelumnya pada responden anak-anak dan remaja di Turki menunjukkan adanya peningkatan PTSD, depresi, dan ketakutan akibat gempa bumi pada kelompok anak-anak dan remaja, masalah psikologis tersebut disebabkan oleh hilangnya kendali atas ketakutan yang disebabkan oleh getaran gempa bumi yang tiba-tiba tak terduga dan tak terkendali. (Şalcıŏlu \& Başoğlu, 2008). 
Masalah psikologis pada usia anakanak dan remaja yang berkaitan dengan bencana alam akan berlangsung lama setelah insiden bencana (Ando et al., 2011; Fergusson, Horwood, Boden, \& Mulder, 2014). Kondisi tersebut akan semakin memburuk bila tidak ditangani dengan baik dan dideteksi sejak awal dengan cara melakukan identifikasi masalah pada korban bencana alam.

Penelitian di Taiwan didapatkan setelah enam minggu pasca gempa bumi yang melanda negara tersebut di dapatkan hasil sebanyak $21,7 \%$ dari 323 siswa menunjukkan masalah stress trauma pasca bencana, penyebab utama dari masalah PTSD tersebut adalah faktor akibat cedera fisik pada anak dan kehilangan atau kematian anggota keluarga akibat gempa bumi (Hsu, Yang, Chong, \& Yen, 2002).

Survei awal untuk melihat dampak psikologis pada anak-anak sangat dibutuhkan untuk menangani berbagai macam permasalahan akibat bencana. Dari penelitian sebelumnya identifikasi dampak psikologis pasca bencana pada anak-anak masih bersifat secara umum yang hanya menggambarkan kondisi psikologis pada anak-anak, sehingga dibutuhkan identifikasi yang lebih spesifik untuk mengetahui kecemasan dan gejala psikologis pada anak paska bencanc. Identifikasi tersebut sangat dibutuhkan untuk menentukan strategi yang tepat dalam penanganan kesehatan mental paska bencana.

Penelitian ini bertujuan untuk mengidentifikasi kecemasan dan gejala psikologis yang terjadi pada anak-anak korban bencana alam gempa bumi di wilayah Lombok, Provinsi Nusa Tenggara Barat.

\section{METODE}

Desain

Penelitian ini merupakan penelitian mix method kuantitatif dan kualitatif. Metode kuantitatif melalui pengisian kuesioner. Metode kualitatif dilakukan dengan metode wawancara tentang sikap dan perilaku anak sebelum dan setelah gempa. Pengumpulan data kualitatif dilakukan setelah hasil kuesioner dinilai sehingga memperkuat data hasil kuantitatif.

\section{Sampel}

Pengambilan sampel dalam penelitian ini ditentukan dengan kriteria purposive sampling. Kegiatan penelitian dilakukan di Sekolah Dasar Negeri 2 Penimbung, Lombok Barat dengan jumlah sekitar 47 anak korban gempa bumi yang berusia enam hingga delapan tahun di wilayah kerja Puskesmas Penimbung.

\section{Instrumen}

Kuesioner RCMAS-2 (Revised Children Manifest Anxiety Scale) yang dikembangkan oleh Reynolds dan Richmond (2008) berisi dua puluh delapan item pernyataan tentang gejala kecemasan untuk menilai tingkat dan kualitas kecemasan yang dialami anak-anak dan remaja usia 6-19 tahun. Interpretasi hasil RCMAS-2 dibagi dalam dua kategori yaitu kecamasan normal jika mempunyai skor $\leq$ 19, dan kecemasan klinis jika mempunyai skor 20-28. Sedangkan data kualitatif didapatkan dengan metode observasi dan wawancara mendalam secara langsung ke orang tua dan guru di SDN 2 Penimbung, Lombok Barat. Peneliti melakukan wawancara mendalam dengan beberapa orang tua dan guru untuk memperoleh tanggapan informasi terhadap sikap dan 
perilaku anak-anak pasca kejadian gempa bumi di Lombok.

\section{Proses Etik}

Kegiatan penelitian untuk mengidentifikasi korban bencana gempa bumi pada anakanak ini dilakukan oleh tim trauma healing dalam fase penanganan pasca bencana di wilayah Lombok. Sebelum kegiatan penelitian dilakukan, responden dan infroman dari orang tua dan guru menandatangani lembar persetujuan pengambilan data (informed consent).

\section{Analisis Data}

Data gambaran karakteristik responden, kategori kecemasan anak-anak korban gempa bumi dianalisis dan dijabarkan menggunakan program Microsoft Excell. Sedangkan gambaran identifikasi dampak psikologis anak-anak didapatkan dari data hasil observasi dan wawancara mendalam, peneliti melakukan transkrip semua hasil wawancara mendalam dari rekaman data, dengan tahapan sebagai berikut: a) Mentranskripkan semua hasil wawancara mendalam dari rekaman data; b) Menganalisis data dengan program Microsoft Excell, kemudian informasi dari transkrip data wawancara dimasukan dan selanjutnya mereduksi data untuk menemukan makna yang sesuai dengan fokus tujuan penelitian.

\section{HASIL}

Karakteristik

Hasil menunjukkan bahwa 55,32\% responden berjenis kelamin perempuan dan 44,68\% berjenis kelamin laki-laki dan. Sebagian besar responden berusia 8 tahun $48,49 \%$.
Dampak Psikologis pada Anak.

Hasil deteksi dini gejala kecemasan pada anak korban gempa menunjukkan bahwa sebanyak $85,11 \%$ orang mengalami kecemasan dalam batas normal, sedangkan $14,89 \%$ termasuk dalam kategori kecemasan klinis.

Tabel 1. Karakteristik Anak Korban Bencana Alam Gempa Bumi di Lombok, Nusa Tenggara Barat September 2018 $(n=47)$

\begin{tabular}{lcc}
\hline Karakteristik & Jumlah & Presentase (\%) \\
\hline Jenis Kelamin & & \\
\hline Laki-laki & 21 & 44,68 \\
\hline Perempuan & 26 & 55,32 \\
\hline Total & 47 & 100 \\
\hline Usia & & \\
\hline 6 tahun & 11 & 23,40 \\
\hline 7 tahun & 13 & 27,66 \\
\hline 8 tahun & 23 & 48,49 \\
\hline Total & 47 & 100 \\
\hline
\end{tabular}

Tabel 2. Deteksi Kecemasan Anak Korban Bencana Alam Gempa Bumi di Lombok, Nusa Tenggara Barat September 2018 $(n=47)$

\begin{tabular}{lcc}
\hline Jenis Gejala & Jumlah & Presentase (\%) \\
\hline Kecemasan Normal & 40 & 85,11 \\
\hline Kecemasan Klinis & 7 & 14,89 \\
\hline Total & 47 & 100 \\
\hline
\end{tabular}

Berdasarkan hasil wawancara mendalam dengan orang tua dan guru di sekolah ditemukan bahwa anak-anak korban gempa menyatakan takut untuk memasuki rumah akibat peristiwa gempa, mengalami gangguan tidur seperti; mimpi 
buruk dan di sekolah langsung menangis jika mendengar suara gaduh, serta ditemukan perubahan sikap seperti mudah tersinggung dan lebih sensitif. Selain itu, anak-anak juga menyatakan bahwa mereka takut karena ada isu makhluk halus, sehingga sering terbangun tiba-tiba pada malam hari. Pernyataan ini didukung dengan jawaban anak-anak pada kuesioner yang menyatakan anak takut dengan apa yang dikatakan oleh orang tua dan sering terbangun karena ketakutan.

Gejala kecemasan klinis yang muncul pada anak korban gempa mempunyai skor 20-23 yang dinilai dari dalam tiga faktor kecemasan yaitu: keterasingan sosial, faktor fisik dan ketakutan berlebih. yang dimanifestasikan dengan merasa sendiri walaupun saat di tempat ramai, khawatir saat akan tidur, susah untuk tidur malam, bermimpi buruk, mudah marah, tangan berkeringat, dan sulit berkonsentrasi dengan tugas di sekolah.

\section{Dampak Psikologis pada Anak Akibat Bencana Alam Gempa Bumi}

Masalah-masalah yang ditemukan pada korban anak setelah bencana alam gempa bumi diantaranya yaitu pertama terjadinya perubahan sikap seperti anak menjadi lebih sensitif, mudah menangis, mudah marah, apabila mendengar sesuatu yang bergemuruh langsung panik dan menangis, sering khawatir masuk rumah, yang awalnya ceria dan cerdas setelah gempa lebih banyak diam dan menarik diri. Gejala-gejala kecemasan klinis yang dialami anak dapat mengarah pada gejala PTSD.

\section{PEMBAHASAN}

Hasil deteksi dini gejala kecemasan pada anak korban gempa di wilayah Lombok menunjukkan bahwa sebanyak
$85,11 \%$ anak-anak mengalami kecemasan dalam batas normal, sedangkan 14,89\% anak termasuk dalam kategori kecemasan klinis.

Meskipun banyak korban bencana pada usia kelompok anak-anak memperlihatkan beberapa jenis reaksi psikologis paska bencana, penelitian klinis menunjukkan bahwa gejala-gejala tersebut tergantung juga pada usia. Penelitian sebelumnya menunjukan bahwa usia adalah faktor kunci pemahaman anak terhadap bencana. Usia sebagai indeks keterampilan perkembangan anak dalam merefleksikan kemampuan memahami apa sebenarnya bencana atau kejadian yang dapat menyebabkan trauma. Penelitian terkait bencana pada kelompok usia anak sekolah secara empiris menyatakan bahwa anak usia sekolah menunjukkan distres psikologis yang lebih menyeluruh (Purnamasari, 2016).

Hasil tersebut dibuktikan dari dampak psikologis pada anak akibat bencana gempa bumi di wilayah Lombok, yang menunjukkan adanya masalah psikologis berupa ansietas klinis dan perubahan perilaku. Adapun masalahmasalah yang ditemukan pada responden setelah bencana alam gempa bumi di Lombok diantaranya yaitu pertama terjadinya perubahan sikap seperti anak menjadi lebih sensitive, mudah menangis, mudah marah, apabila mendengar sesuatu yang bergemuruh langsung panik dan menangis, sering khawatir masuk rumah, adanya gangguan pola tidur, hingga anakanak lebih banyak diam dan menarik diri dengan ketergantungan yang tinggi terhadap orang tua.

Hasil penelitian sebelumnya juga memfokuskan pada variasi reaksi anak usia sekolah pasca bencana gempa dapat 
bervariasi sesuai dengan jenis kelamin atau usia. Dampak psikologis yang dirasakan oleh korban terutama pada mayoritas populasi anak-anak ialah menyangkut kondisi trauma mental yang sangat serius. Anak-anak menunjukkan gejala-gejala perilaku seperti; susah tidur, rasa takut yang berlebihan, takut masuk rumah, tidak mau tidur di dalam rumah, diliputi kecemasan dan menarik diri (Astuti, 2006).

Hal tersebut juga sejalan dari hasil penelitian Bedriye pada anak-anak usia sekolah di Turki pada tahun (2014) mendapatkan hasil berupa reaksi anak pasca bencana gempa adalah penghindaran, menjadi marah, mencela diri sendiri, dan perubahan perilaku seperti gejala; memiliki mimpi tentang gempa, takut tinggal di dalam rumah, diganggu dengan suara dan suara yang tiba-tiba, setelah tidur kesulitan, keengganan untuk pergi ke sekolah dan bergabung dalam permainan (Bedriye, 2014).

Pada penelitian yang lain juga menunjukkan kemunduran anak-anak dalam kegiatan belajar di sekolah setelah kejadian bencana. Secara khusus masalah pasca bencana dan diskontinuitas kondisi kehidupan menyebabkan maslah-masalah di lingkungan akademik sekolah. Anak tidak tertarik dengan aktifitas sekolah dikarenakan masalah somatik seperti sakit yang dapat mempengaruhi kehadiran sekolah, sehingga anak korban bencana akan mengalami penurunan keterampilan dan prestasi belajar akademik di sekolah (Gurwitch, Kee, Becker, \& Schreiber, 2015). Secara umum masalah psikologis pada anak pasca bencana menunjukkan setiap kali bencana yang terjadi selalu diikuti oleh kondisi trauma pasca bencana PTS. Minimal PTSD yang terjadi merupakan rangkaian gejala dari masalah pada tingkat menengah sampai dengan ke tingkat yang berat (Purnamasari, 2016).

Secara keseluruhan, pada anak-anak usia sekolah yang selamat dari bencana alam khususnya bencana gempa bumi sering memperlihatkan adanya gejala ketakutan pada tingkat yang tinggi, gejala somatik yang luas, masalah kognitif, perubahan perilaku dan masalah sosial. Masalah kognitif meliputi kurang konsentrasi, permasalahan kegiatan belajar, hingga perilaku menolak datang ke sekolah. Perilaku anak menjadi tidak konsisten seperti mudah marah, tidak sopan dan secara emosional yang menjadi sensitif. Oleh karena itu, sangat diperlukan suatu tindakan pelayanan kesehatan pasca bencana untuk menangani masalah-masalah psikologis yang sering muncul pada kelompok anakanak.

\section{KESIMPULAN DAN SARAN}

Bencana alam gempa bumi yang dialami oleh masyarakat wilayah Lombok provinsi Nusa Tenggara Barat tidak hanya berdampak pada kondisi fisik dan lingkungan namun juga berdampak pada kondisi psikologis anak korban gempa seperti adanya gejala kecemasan normal dan kecemasan klinis yang mengarah pada PTSD yang ditunjukkan dari perubahan perilaku anak. Gejala tersebut dirasakan anak di rumah maupun di sekolah. sehingga hal ini akan membutuhkan penanganan lebih lanjut, seperti pelayanan kesehatan pasca bencana seperti kegiatan trauma healing.

Penelitian selanjutnya diharapkan untuk melakukan terapi seperti bermain, menggambar, mendongeng dan sebagainya untuk mengurangi dampak psikologis akibat gempa, memberikan pengetahuan 
tentang gempa dan mengedukasi keluarga dan teman tentang perubahan perilaku dan masalah yang mungkin dihadapi anakanak.

\section{UCAPAN TERIMA KASIH}

Penelitian ini didukung dan dibiayai oleh Fakultas Kedokteran, Universitas Diponegoro, bekerjasama dengan Stikes Yarsi Mataram, pihak Puskesmas Penimbung dan tokoh masyarakat Desa Penimbung yang bekerjasama dalam proses rangkaian kegiatann penelitian.

\section{DAFTAR PUSTAKA}

Ando, S., Kuwabara, H., Araki, T., Kenehara, S., Morishima, R., Kondo, S.,...Kasai, K. (2017). Mental health problems in a community after the great East Japan earthquake in 2011: A Systematic review. Harvard Review of Psychiatry, 25(1), 15-28. doi: 10.1097/HRP.000000

Astuti, B. (2006). Layanan bimbingan dan konseling bagi korban gempa bumi di Yogyakarta. Makalah. Jurusan Psikologi Pendidikan dan Bimbingan, Fakultas Ilmu Pendidikan, Universitas Negeri Yogyakarta.

Badan Meteorologi dan Geofisika. 2018.

Bedriye, A. K. (2014). Determination and evaluation of effect of earthquake on school age children (6-12 years old) behaviours. Procedia-Social and Behavioural Science, 152, 845-851. doi: 10.1016/j.sbspro.2014.09.332

Fergusson, D. M., Horwood, L. J., Boden, J. M., \& Mulder, R. T. (2014). Impact of a major disaster on the mental health of a well-studied cohort. JAMA Psychiatry, 71(9), 1025-31.

doi:10.1001/jamapsychiatry.2014.65

Gurwitch, R. H., Kees, M., Becker, S. M., \& Schreiber, M. (2004), Assessment of PTSD among Indonesian children. Prehospital and Disaster Medicine, 46(5), 1921-8.

Hsu, C., Chong, M., Yang, P., \& Yen, C. (2002). Posttraumatic stress disorder among adolescent earthquake victims in Taiwan. APAPsycNET, 41(7), 875-881. doi: 10.1097/00004583200207000-00022

Nakamura, Y. (2005). Public health impact of disaster on children. JMAJ, 48(7), 377-384.

Purnamasari, I. (2016). Perbedaan reaksi anak dan remaja pasca bencana. Jurnal Penelitian dan Pengabdian kepada Masyarakat, 3(1), 49-55. doi: 10.32699/ppkm.v3i1.336

Ramirez, M., \& Peek-Asa, C. (2005). Epidemiology of traumatic injuries from earthquakes. (online) Diperoleh dari http://epirev.oxfordjournals.org/cont ent/27/1/47.extract

Reynolds, C. R. \& Richmond, B. O. (2008). $\quad$ (RCMAS $\left.{ }^{\mathrm{TM}}-2\right) \quad$ Revised Children's Manifest Anxiety Scale ${ }^{\mathrm{TM}}$, Second Edition. Diperoleh dari https:www.wpspublish.com/store/im ages/downloads/product/rcmas2_manual_chapter_1.pdf.

Şalcıŏlu, E., \& Başoğlu, M.. (2008). Psychological effects of earthquakes in children: prospects for brief 
behavioural treatment. Wold Journal Pediatrics, 4(3), 165-172. doi: $10.1007 / \mathrm{s} 12519-008-0032-8$

Surendra S., Samuel, R., Marahatta, K, Anwar, N., Van Ommeren, M. H., \& Ofrin, R.. (2017). Post-disaster mental health and psychosocial support: Experience from the 2015 Nepal earthquake. WHO South-East Asia Journal of Public Health, 6(1), 22-29. doi: 10.4103/22243151.20616 